\title{
Organizing the Future of Villages: Strengthening the Rural Economic Institutional
}

\author{
Deddy Winarwan \\ Gajah Mada University, Yogyakarta, Indonesia
}

\{deddywinarwansstp@gmail.com\}

\begin{abstract}
The existence of a village, either as a government institution or as a customary law community unit, becomes very important and has a strategic role in achieving the national development goals. In Indonesia, there are 16 thousand villages that categorized as a remote, poor and abandoned villages. This condition is on contraty to the objectives of the regional autonomy namely to expand public welfare. Government policy rarely responds the local dynamics of rural areas. The implementation of Law of The Republic of Indonesia Number 6 of 2014 on Village mandates that villages must be independent socially, culturally, economically, and politically. The strategic measurement that has to be put forward by the government to solve this problem is to strengthen rural economic institutions within the framework of national development through an affirmative policy model for strengthening the rural economic institutions in Indonesia.
\end{abstract}

Keywords: Institutional Strengthening; Rural Economy; National Development

\section{Introduction}

Villages as a unit of the legal community have put themselves as a mixed (hybrid) unit of the self-governing community and local self-government. As the smallest unit of a country, villages have the closest position to the community and in real direct contact with the community to realize their welfare. A strong rural social system is a power to develop political, social, cultural, and economic systems. In Indonesia, there are 74,961 villages (Decree of the Minister of Home Affairs Number 146.1-4717 of 2020 concerning Stipulation of Names, Codes and Number of Villages throughout Indonesia in 2020), of which more than 16.426 villages are categorized into remote ones (Village Build Index 2020). This condition is on contrary to the objectives of regional autonomy. In the era of regional autonomy, it shall be a realization to show the power in various fields, since the main goal of regional autonomy is to expand community welfare, including rural communities. To achieve the goal of national development, villages are the leading government agencies that can reach real target groups who will be prosperous, meanwhile in fact, many research results are indicating that national development is discriminatory against the village, at least in the last decade.

The issuance of Law Number 6 of 2014 on Village mandates the autonomy rural to manage its government and community. Government Regulation Number 43 of 2014 as has been amended by Regulation Number 47 of 2015 stated that recently villages have the authority to manage their own resources and development direction. For such purpose, the basis of rural life dynamic is very much based on community participation in the realization of 
village management agreements, abbility to increase and develop social, cultural, economic, and knowledge values. The effectiveness of the regulation on the village has given hopes for the rural community to change. It will be a momentum to encourage the birth of village with more accountable and transparent governance, participatory rural communities, and supporting economy village.

Villages face a new era. Law Number 6 of 2014 on the Village, views villages as life support. Villages are expected to be independent socially, culturally, economically, and even politically. Villages now enter the self-governing era where villages have the autonomy and authority to plan, provide public services and manage finance. Then villages do not only wait for the instructions from supra villages (Sub-District, Regency, Province, and Central Government).

By the identification of the issues mentioned above, the issue formulation in this study is: What is the model for strengthening rural economic institutional in Indonesia?

\section{Results and Discussion}

\subsection{Rural Development and Empowerment}

National development is a series of sustainable development efforts and covers all community life, nation, and the state to perform the duty to realize the national goal that is to protect the whole people of Indonesia, advance general prosperity, develop the nation's intellectual life, and contribute to the implementation of a world order based on freedom, eternal peace, and social justice. The essence of national development is the development of the Indonesian human being as a whole and the development of the entire Indonesian society with Pancasila (five principles) as the foundation, goal, guideline for community development. National development is aimed at realizing justice and prosperity that is just and prosperous based on Pancasila and the 1945 Constitution of the Republic of Indonesia.

Through the stipulation of Law Number 6 of 2014 concerning Villages, Government Regulation Number 43 of 2014 concerning the Implementation Regulations of Law Number 6 of 2014 concerning Villages, as well as Government Regulation Number 60 of 2014 concerning Village Finance, then directly changes the perspective of national development. Through the new paradigm in development, directly or indirectly, it is hoped that it can project that welfare and economic development do not have to be in urban or urban areas, but in the national development process, it must start from the village. The village is the spearhead and is the vanguard of the national development process in order to achieve prosperity and wellbeing, at the same time being fair and sustainable.

Law Number 6 of 2014 concerning Villages has two approaches that are integrated into Village Development planning, namely "Developing Villages" and "Village Develops". Besides, this Law mandates that Village Development is an effort to improve the quality of life and life for the maximum welfare of the Village community. Village Community Empowerment is an effort to develop community independence and welfare by increasing knowledge, attitudes, skills, behavior, abilities, awareness, programs, activities, and assistance in accordance with the essence of problems and priority needs of the Village community. It is hoped that in the future the Village can make changes and governance of effective government administration, effective development implementation, as well as community development and community empowerment in the region, in other words, the national development paradigm must develop Indonesia that starts from the village. 
The sustainable village development policy according to Law Number 6 of 2014 is the right choice to encourage the process that leads to the goals of village development itself. However, the challenge that is generally faced by rural communities in Indonesia is poverty which traps both in structural and cultural dimensions. Poverty and neglected environmental conditions in rural areas, such as forming a vicious circle process that never ends: being poor because of the damaged environment, and the environment being damaged due to the outbreak of acute poverty in the community. Narayan, et. al (2000) revealed evidence from the results of studies in various countries, including Indonesia, that poverty and ecological damage in rural areas are closely related to one another so that it becomes part of the community to enter a deeper and more difficult poverty gap overcome. And poverty like this is multi-dimensional, which is known as "ill-being" or the low quality of life.

This finding is in line with the results of the study by Winarwan (2012) which shows that the same policy, applied in the same poor community, and the same rural area, actually gives rise to different responses, because there is social differentiation so that different consequences arise. Therefore, it is necessary to develop an affirmative policy model. With this model, it is hoped that it will become the main solution to the socio-structural problems faced by structurally poor marginalized people. The problem of poverty as a result of the unfair distribution of benefits of national development in the past is an incomplete homework for the Government, so it is necessary to formulate appropriate affirmative policies in the efforts of affirmative action that side with the poor in realizing people's welfare as mandated in the 1945 Indonesian Constitution.

\subsection{Strengthening Rural Economic Institutions}

Indonesian Economy is basically an economic model based on the market mechanism in which government intervention plays an important role. In accordance with 1945 Indonesian Constitution Chapter XIV, Article 33, the Indonesian economy shall be organized as a common endeavor based upon the principles of the family system, with sectors of production that are important for the country and affect the life of the people shall be under the powers of the State and shall be used to the greatest prosperity of the people. The role of the government shall include all Indonesian territories, not only in urban areas but also in rural areas.

The existence of villages both as government agencies and entities customary law community become very important and strategic. The village is the basis of a strong Indonesian social system so that it can be a strong foundation for national development and economy. Therefore, rural development has a significant role in the success of national development. The objective of rural development is to improve the quality of human life and reduce poverty, by providing basic needs fulfillment, developing infrastructure, developing local development potencies, and utilizing natural resources and the environment sustainably, promoting unity, brotherhood, and mutual cooperation.

Speaking rural development will certainly relate to the discussion about the rural economy, but we should not forget that the conditions of social capital of rural communities are very strong. The rural community has various social bonds and very social solidarity, as the important pillars for government activities, and community. Independence and mutual cooperation have been proved as the main pillar of rural "original autonomy". Although on the other hand, social capital wealth is inversely proportional to economic capital. Rural social capitals consist of social bonding, social bridging, and social linking. Of those three aspects, rural social bonding that is parochial (limited) becomes the shallowest social capital that is unable to facilitate economic development, realize the social-powered villages and local 
democracy (Eko et al., 2014). Village Law and its derivative regulation explicitly have opened space for such movement.

Considering enormous affirmative policy as Law Number 6 year 2014 concerning Village has an opportunity to make a huge change for local government and communities all over Indonesia. Therefore, it is necessary to build an integrated norm of rural implementation in the form of "village develops" (bottom-up approach) and "developing village" (top-down approach) (Winarwan, 2016).

The growth of the rural economy is often assessed slower than urban economic development. The rural economy arrangement shall be performed by utilizing rural resources optimally in accordance with the conditions and community needs to achieve complete and sustainable welfare. To achieve them, it is required two approaches: (a) The needs of people in their efforts to change and prevent undesired things; and (b) the political will and ability of rural government along with the community to implement rural development that has been prepared (Rustiadi, 2001 in Bachrein, 2010). Village resource potency so far has not been utilized optimally. If one utilizes them, the utilization tends to be exploitative and does not consider the impact caused by the village resource exploitation.

One important solution that is able to boost the movement of the rural economy is developing Village-Owned Enterprises (BUMDes). Development of Village-Owned Enterprises (BUMDes) offers a solution to reduce poverty, migration, and development of employment in the village. By virtue of Law Number 6 of 2014, villages may establish Village-Owned Enterprises (BUMDes) managed with the spirit of family system and mutual cooperation. BUMDes (Village-Owned Enterprises) is a company managed by rural communities and its management will be separated from the village government. BUMDes (Village-Owned Enterprises) establishment aims to explore and optimize the potency of rural entrepreneurs. BUMDes (Village-Owned Enterprises) represents the village government to develop local economic potency and to provide public services for the rural community.

Rural development can be improved through the development of the rural economic potency and within the same rural community institution to develop themselves and their environment independently and participatory. The existence of BUMDes (Village-Owned Enterprises) will be a consideration to channel rural community's initiative, develop rural potency, manage and exploit rural natural resources, optimize human resources (villagers) in managing the BUMDes (Village-Owned Enterprises) and the capital participation from the village government in the form of handed over rural financing and wealth to be managed as the part of BUMDes (Village-Owned Enterprises).

In the broad line, rural community through the Village's Consultative Agency is actively participated in the processes of: initiation, establishment (including establishing the managing organization, business capital, and Article of Association), receiving progress reports at least twice a year. The villagers are involved through the mechanism of villager representatives in the Village Consultative Agency in determining Peraturan Desa (Village Regulation) on BUMDes (Village-Owned Enterprises) establishment and supervising the responsibility of village government to develop village-owned enterprises. BUMDes (Village-Owned Enterprises) is not established to perform the activity of main productive economic in utilizing local natural resources. BUMDes (Village-Owned Enterprises) role is to support, facilitate and coordinate the productive economic activities based on natural resource utilization by the villagers.

BUMDes (Village-Owned Enterprises) is expected to be able to stimulate and drive the rural economy wheel. Rural economic assets shall be managed entirely by the villagers. BUMDes (Village-Owned Enterprises) substance and philosophy shall be ensouled by the 
spirit of togetherness and self-help as an effort to strengthen the aspect of institutional economics. At this stage, BUMDes (Village-Owned Enterprises) will move in harmony with the efforts to increase the sources of locally generated revenue, driving community economic activities in which BUMDes (Village-Owned Enterprises) role is an umbrella to provide shade. This effort is also important to reduce the role of free-riders who often increase transaction costs in economic activities through the practice of rents Patron-Client.

BUMDes (Village-Owned Enterprises) runs the businesses in the economic sector and/or public service. This institution is not only oriented to financial benefits but also supports the welfare increase. Business income is used to grow the business and rural development, empower the villagers and provide assistance for the poor through grants, social assistance, and revolving fund.

In accordance data from the Ministry of Village, Development of Remote Areas and Transmigration, amid the weakening of various business sectors due to Covid-19, until July 2020 there are 10.026 BUMDes (Village-Owned Enterprises), are still holding out and continuing to carry out economic transactions. Although most of these BUMDes (VillageOwned Enterprises) still face various problems, such as:

a. The difficulties of developing superior products

b. High and not standardized production cost

c. Marketing limitations, only marketed at the local level

d. The risk of BUMDes (Village-Owned Enterprises) bankruptcy affects the Village Revenue and Expenditure Budget (APBDes)

The enactment of Government Regulation Number 11 of 2021 concerning BUMDes, aims to increase the economic activities of local village communities, overcome various problems faced by most BUMDes (Village-Owned Enterprises) and promote the economic independence of villages in Indonesia.

Based on the description above, strengthening rural economic institutions through the development of BUMDes still faces various obstacles. Concerning these facts, an affirmative policy model is recommended to optimize the role and function of BUMDes (Village-Owned Enterprises) and drive the dynamics of the rural economy, which are adjusted to the very diverse characteristics and conditions of each village, so it is necessary to develop a BUMDes affirmative policy model as follows:

a. Legal entity establishment of all BUMDes (Village-Owned Enterprises)

b. Increased BUMDes (Village-Owned Enterprises) legal status

c. Preparation of BUMDes (Village-Owned Enterprises) business development planning guidelines

d. Increased cooperation opportunity preparation of cooperation $\mathrm{MoU}$ between BUMDes (Village-Owned Enterprises) with third parties to strengthen BUMDes (Village-Owned Enterprises) both in terms of investment and product marketing

e. Accelerated new products innovation from BUMDes (Village-Owned Enterprises) so that will emerge superior products

f. Assistance by the Ministry/Government agencies and stakeholders involved in BUMDEs product's quality control.

Considering the position of the village-owned enterprises to face of violent penetration domestic and foreign capital that recently makes village the target of business development, then the position of village-owned enterprises is very vital and strategic. With rural natural resources, villages are susceptible to capital and market intervention. The existence of villageowned enterprises is expected to be a deterrent for foreign and domestic corporation power. It is expected that village-owned enterprise is able to drive rural economy dynamics. BUMDes 
(Village-Owned Enterprises) has a strategic role as one of the main interventions of village government to improve villager's welfare through improved public services, economic growth, and equal distribution of Village economy. Participation of APBN support for village development is through Village Fund in the development of BUMDes (Village-Owned Enterprises) is a complementary intervention format to provide the possibility for the village government to actively develop local economy collectively based on each village potency and capability.

\section{Conclusion}

Villages are the government's forefront to achieve national development goals because they can reach the real target groups namely people to be prospered. Law No. 6 of 2014 on the Village, has mandated the villages as the life support. Villages are expected to be independent socially, culturally, economically, and even politically. It is also supported by Joko WidodoMa'ruf Amin government's commitment to organize and develop village. Village economy institutional strengthening within the framework of national development is a strategic choice that is expected to be able to realize village independence to face the reality of rapid domestic and foreign capital intervention that recently makes the village as the business development goals.

To support that effort, an affirmative policy model for the development of BUMDes in Indonesia includes the establishment of legal entity and improved BUMDes (Village-Owned Enterprises) legal status, BUMDes (Village-Owned Enterprises) business development planning preparation guidelines, increased opportunities for cooperation with third parties, accelerating innovation of BUMDes (Village-Owned Enterprises) superior products with an assistance by the Ministry/government agencies and stakeholders.

\section{References}

[1] Eko, S. et al. 2014. Desa Membangun Indonesia (Village Builds Indonesia). Yogyakarta: Forum Pengembangan Pembaharuan Desa.

[2] Bachrein, Saeful. 2010. Developing Village Approach in West Java: Rural Development Policy and Strategy. Analisis Kebijakan Pertanian. Volume 8 No. 2, Juni 2010.

[3] Sen, A. 2000. Development as Freedom. New York: Amchor Books, Random House, In.

[4] Baker, Susan. 2006. Sustainable Development. London and New York: Routledge.

[5] Gibson, C., M. Woolcock. 2008. Empowerment, Deliberative Development, and LocalLevel Politics in Indonesia: Participatory Projects as a Source of Countervailing Power. in the St Comp Int Dev. Year 2008 No. 43.

[6] Narayan, Deepa. et al. 2000. Voices of the Poor : Crying Out for Change. New York: Oxford University Press for the World Bank.

[7] Li, Tania Murray. 2007. The Will to Improve: Governmentality, Development, and the Practice of Politics. Durham \& London: Duke University Press.

[8] Semedi, Pujo. 2003. Close to the Stone, Far from the Throne. Bandung: Benang Merah Press. 
[9] Winarwan, Deddy. 2012. Policy of Forestry Management, Structural Poverty and Resistance of Forestry Village Community in the Province of Lampung. Ph.D. dissertation. Yogyakarta: UGM Postgraduate School.

[10] Winarwan, Deddy. 2016. Revitalization of Village Governance In National Development. International Workshop: New Law, New Villages: Changing Rural Indonesia. Leiden: KITLV in collaboration with Leiden University's Van Vollenhoven Institute and the Asian Modernities and Traditions program (AMT), and the Norwegian Centre for Human Rights at the University of Oslo (NCHR). 